\title{
Rediscovery of Dicliptera leonotis (Acanthaceae) from Maharashtra, India
}

\author{
Kumar Vinod Chhotupuri Gosavi ${ }^{1}$, Sanjay Gajanan Auti ${ }^{1}$, Karan Rana ${ }^{2}$ \& S.S. Kambale ${ }^{3^{*}}$ \\ 'Department of Botany, HPT Arts \& RYK Science College, Nashik - 422 005, Maharashtra, India. \\ 2 School of Science, Navrachana University, Vadodara - 391 410, Gujarat. \\ ${ }^{3}$ Department of Botany, Maratha Vidya Prasarak Samaj's Arts, Commerce \& Science College, \\ Tryambakeshwar - 422 212, Maharashtra, India. \\ *E-mail: skambalesu@gmail.com
}

\begin{abstract}
Dicliptera leonotis Dalzell ex C.B.Clarke is rediscovered after a gap of 144 years. A detailed description, colour photographs and taxonomic notes are provided.
\end{abstract}

Keywords: Anjaneri hills, Dicliptera leonotis, Endemic, northern Western Ghats.

\section{Introduction}

The genus Dicliptera Juss. comprises 150 species distributed in tropical and warm areas of the world (Mabberley, 2017). The genus is known to have 21 species and nine varieties in India (Karthikeyan et al., 2009), of which eight species occur in Maharashtra (Moorthy, 2001). While surveying Anjaneri hills, Nashik district, in Maharashtra, the authors collected an interesting Dicliptera species. After perusal of relevant literature (Clarke, 1885; Moorthy, 2001) and the type specimen housed at $\mathrm{K}$, it has been identified as Dicliptera leonotis Dalzell ex C.B.Clarke.

Dicliptera leonotis was described by Clarke (1885) based on the specimen collected by Dalzell in 1874 from Anjaneri hills. In the Flora of Nashik district (Lakshminarasimhan \& Singh, 1987) and Maharashtra state (Moorthy, 2001) it has been included based on Dalzell's collection. Balkwill et al. (1996) mentioned its occurrences in tropical Africa based on Clarke's treatment (1900). Barker (1986) discussed the status of $D$. leonotis and mentioned that whatever has been identified as 'D. leonotis' in the Flora of Queensland by Bailey $(1901,1913)$ is D. ciliata Decne. However, D. ciliata is a species which

Received: 27.08.2018; Revised \& Accepted: 20.06.2019 Published Online: 30.06.2019 shows the cleistogamous flowers (Barker 1986) which are lacking in D. leonotis. Therefore, the African material is treated as D. ciliata rather than D. leonotis. Backer and Brink (1965) erroneously applied the name D. leonotis to Javan material. However, Barker (1986) and Nayar et al. (2014) mentioned that D. leonotis occurs in Africa based on the aforesaid literature and hence has not been treated as an endemic taxon for India. Karthikeyan et al. (2009) mentioned that it's an endemic species of peninsular India based on the personal communication with Balkwill. Balkwill et al. (1996) reported D. burmanni from India, China and Timor which was treated under synonymy of $D$. leonotis by Clarke (1885). Clarke (l.c.) had included the African specimens within the circumscription of D. leonotis, however, Darbyshire (2015) accepted it as form 'C' of Dicliptera clinopodia Nees. However, it differs from $D$. leonotis in having much smaller bracts. According to Darbyshire (l.c.) D. leonotis is an Indian species and does not occur in Africa (Pers. Comm.: Darbyshire). Critical examination of specimens of D. burmanni at $\mathrm{K}$ and $\mathrm{P}$ and the illustration in the protologue (Nees, 1832), revealed it as distinct and does not occur in India.

Dicliptera leonotis was reported from Gujarat by Bedi (1968) and based on Bedi's authority it was included in Flora of Gujarat (Shah, 1978; Raghavan et al., 1981; Jani, 2014). However, the authors could trace the specimens of Bedi at BARO (Bedi 2472) and critical examination revealed it to be $D$. micranthes Nees. The whorled arrangements of the flowers as in D. leonotis might be the reasons of the confusion.

Therefore, it is clear that D. leonotis is an endemic species of northern Western Ghats of Maharashtra 

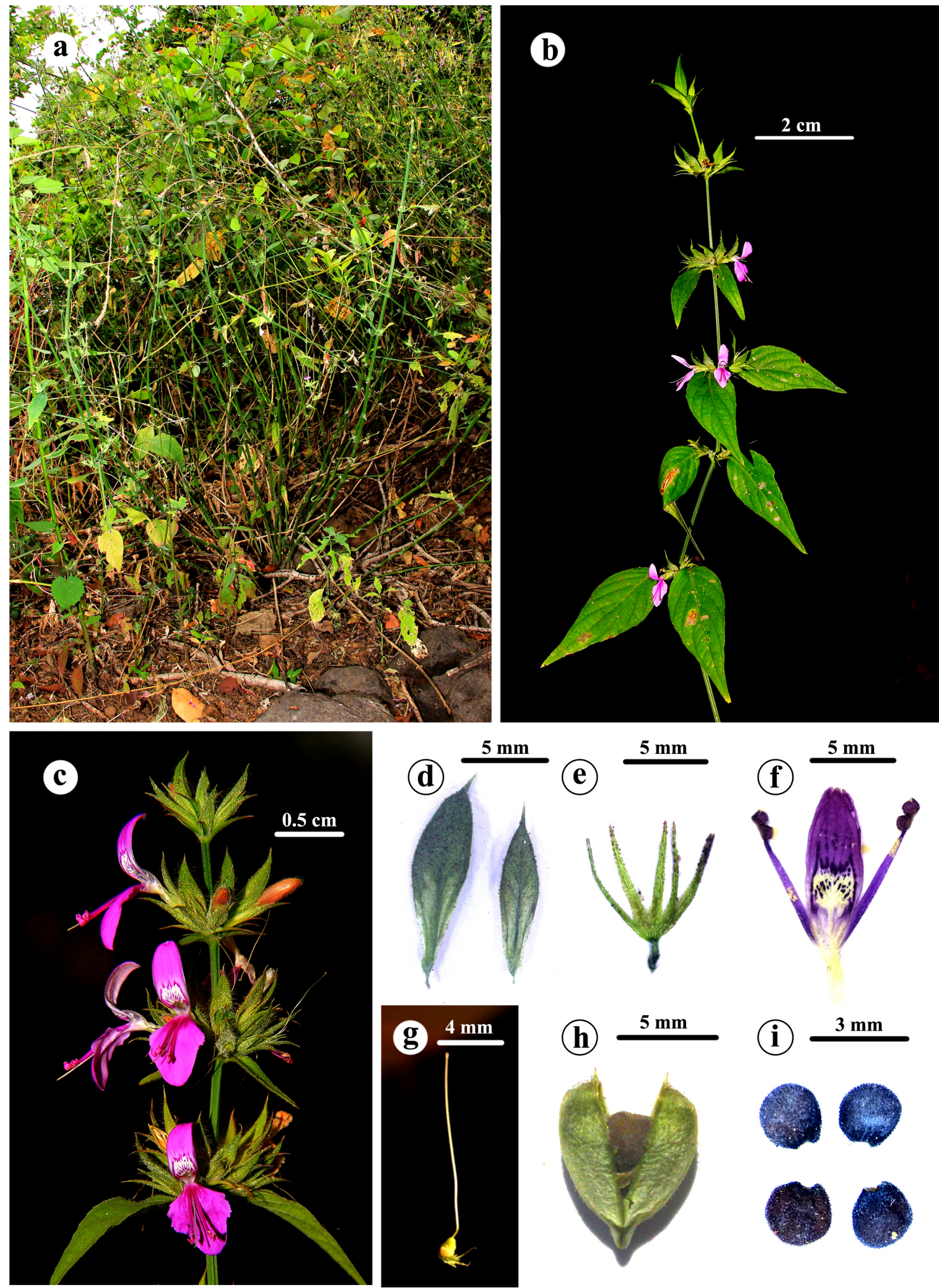

Fig. 1. Dicliptera leonotis Dalzell ex C.B. Clarke: a. Habit; b. Flowering twig; c. Inflorescence; d. Bracts; e. Calyx; f. Upper lip of corolla and stamens; g. Pistil; h. Fruit; i. Seeds. 
and has not been collected since the type collection. It has been recollected now from the type locality after a gap of 144 years.

Dicliptera leonotis Dalzell ex C.B.Clarke in Hook.f., Fl. Brit. India 4(12): 553. 1885.

Fig. 1

Perennial herbs. Stems 1-1.5 m tall, branched, 5-6-angular, hairy. Leaves decussate; petioles $0.5-1.5 \mathrm{~cm}$ long; lamina membranous, $3-12 \times$ $1-4.5 \mathrm{~cm}$, lanceolate-elliptic to ovate, margins undulate, obtuse to acuminate at apex, attenuate at base, raphids irregularly arranged on both surfaces. Cymes umbellate, axillary or terminal, sessile to sub-sessile cluster. Flowers sessile, 1 to few in same bract; bracts 2, unequal to sub-equal, 9-12 × 2-3 $\mathrm{mm}$, lanceolate, acuminate, cuspidate, attenuate at base, glandular pubescent, 3-nerved; bracteoles $1-2,6.5-7 \times 0.5-0.6 \mathrm{~mm}$, linear, apex acute to obtuse, glandular pubescent. Sepals 5 , fused at base, 5-6 $\times 0.5-0.6 \mathrm{~mm}$, linear elliptic to linear ovate, obtuse at apex, glandular hairy. Corolla $c .1 .5 \mathrm{~cm}$ long, bilabiate, hairy outside, dark pink; lips 6-7 $\mathrm{mm}$ long, oval to elliptic; upper lip 3-lobed, lower entire, orbicular. Stamens 2; filaments hairy, 6-8 $\mathrm{mm}$ long, pink; anthers two with unequal lobes, c. $2 \mathrm{~mm}$ long, dehisce through upper slits. Ovary c. $1.5 \mathrm{~mm}$ long; style slender, c. $12 \mathrm{~mm}$ long; stigma bifid. Capsules ovoid, 5.5-6 × 3-3.5 mm, mucronate at apex, glandular hairy, 4-seeded. Seeds orbicular, compressed, 2-2.5 × 2-2.5 mm, with black tubercles, glaucous.

Flowering \& fruiting: November-February.

Habitat: Grows under forest shade at $1000 \mathrm{~m}$ elevation along with Achyranthes coynei Santapau, Carissa carandas L., Elaeagnus conferta Roxb., Olea dioica Roxb., Oplismenus compositus (L.) P.Beauv., Solanum anguivi Lam. and Syzygium cumini (L.) Skeels.

Distribution: Known only from the type locality.

Specimens examined: INDIA, Maharashtra, Nashik district, Tryambakeshwar, Anjaneri, 30.12.2017, S.S. Kambale \& S.G. Auti 478 (BSI!, CAL!); ibid., 14.01.2018, K.V.C. Gosavi, S.S. Kambale \& S.G. Auti 479 (BSI!, CAL!).

Notes: Dicliptera leonotis resembles D. burmanni in having whorled spikes but differs in having acuminate, glandular bracts (vs mucronate, glabrous bracts). While from $D$. ciliata it differs in lacking cleistogamous flowers. D. leonotis differs from D. clinopodia in having pink flowers (vs purple flowers) and eglandular filaments (vs glandular filaments). D. micranthes has small white flowers and pubescent mucronate bracts (vs large pink flowers and glandular hairy bracts in D. leonotis).

\section{Acknowledgements}

Authors thank Dr. I. Darbyshire (K) and Dr. K. Balkwill (University of Witwatersrand, Johannesburg, South Africa) for the comments on the occurrence of D. leonotis in Africa and literature respectively; Principals of H.P.T. Arts \& R.Y.K. Science College, Nashik and Arts, Commerce \& Science College, Tryambakeshwar for the necessary facilities. SGA is thankful to Board of College and University Development, Savitribai Phule Pune University, Pune for financial assistance, authorities of Maharashtra Forest Department for necessary help and permission to work in the Anjaneri Protected Area.

\section{Literature cited}

BACKER C.A. \& B. VAN D.R.C. BRINK 1965. Flora of Java 2: Groningen, The Netherlands). pp. 464-483.

BAILEY F.M. 1901. Acanthaceae. In: The Queensland Flora. Volume 4. H.J. Diddams, Brisbane. pp. 1140-1153.

BAILEY F.M. 1913. Acanthaceae. In: Comprehensive Catalogue of Queensland Plants both indigenous and naturalized. Govt. Printer, Brisbane. pp. 373-374.

BALKWILL K., NORRIS F.G. \& M. BALKWILL 1996. Systematic Studies in the Acanthaceae; Dicliptera in Southern Africa. Kew Bulletin 51(1): 1-61.

BARKER R.M. 1986. A taxonomic revision of Australian Acanthaceae. Journal of the Adelaide Botanic Gardens 9: $1-286$.

BEDI S.J. 1968. The flora of Ratanmahal hills in Panchmahals. Volume 1. Ph.D. thesis. Submitted to The Maharaja Sayajirao University of Baroda, Vadodara. pp. 512-513 (unpublished).

CLARKE C.B. 1885. Acanthaceae. In: HOOKER J.D. (ed.), The Flora of British India Volume 4. Reeve \& Co., London. p. 553

CLARKE C.B. 1900. Acanthaceae. In: THISELTONDYER W.T. (ed.), Flora of Tropical Africa. Volume 5: Reeve \& Co., London. pp. 44-262.

DARBYSHIRE I. 2015. Dicliptera. In: TIMBERLAKE J.R. \& E.S. MARTINS (eds.), Flora Zambesiaca. Volume 8(6). Royal Botanic Gardens, Kew. pp. 250-295. 
JANI M.D. 2014. Bridging the knowledge gaps and developing an interactive system for identification of Gujarat flora. Ph.D. thesis submitted to Sardar Patel University, Vallabh Vidyanagar (unpublished).

KARTHIKEYAN S., SANJAPPA M. \& S. MOORTHY 2009. Flowering plants of India - Dicotyledons. Volume 1 (Acanthaceae - Avicenniaceae). Botanical Survey of India, Kolkata. pp. 160-164.

LAKSHMINARASIMHAN P. \& B.D. SHARMA 1991. Flora of Nashik District. Botanical Survey of India, Kolkata. p. 644

MABBERLEY D.J. 2017. Mabberley's Plant-Book: A portable dictionary of plants, their classification and uses. Edition 4. Cambridge University Press, Cambridge.

MOORTHY S. 2001. Acanthaceae. In: SINGH N.P., LAKSHMINARASIMHAN P., KARTHIKEYAN S.
\& P.V. PRASANNA (eds.) Flora of Maharashtra State, Dicotyledonae 2. Botanical Survey of India, Kolkata. pp. 345-357.

NAYAR T.S., BEEGAM A.R. \& M. SIBI 2014. Flowering plants of the Western Ghats, India. Volume 1. Jawaharlal Nehru Tropical Botanical Garden \& Research Institute, Thiruvananthapuram.

NEES C.G.D. VON ESENBECK 1832. In: WALLICH N. (ed.) Plantae Asiaticae Rariores Volume 3. Richard Taylor, London.

RAGHAVAN R.S., WADHWA B.M., ANSARI M.Y. \& R.S. RAO 1981. A Checklist of Plants of Gujarat. Records of the Botanical Survey of India. p. 127

SHAH G.L. 1978. Flora of Gujarat. Volume 1. Sardar Patel University, Vallabh Vidyanagar. p. 074 